\title{
VAGUENESS, AUTONOMY, AND R V BROWN
}

\author{
DAVID ARNOLD
}

\section{CONTENTS}

Introduction . 101

I Tort Law and Criminal Law

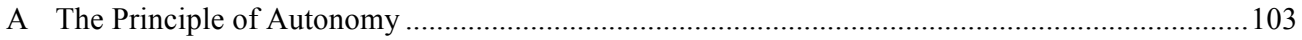

B The Competing Principles of Autonomy and Bodily Integrity ................................................. 103

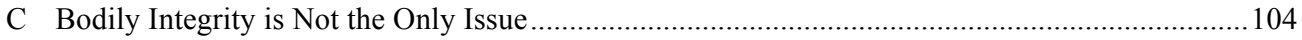

D What Tort Law Says About Consent ............................................................................................ 104

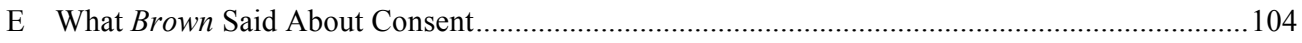

F The Coherence Factor............................................................................................................ 105

II Vagueness, The Rule of Law and Limits on State Power .......................................................................105

A Vagueness of the Statute in Brown..............................105

B The Rule of Law and Restrictions on State Power ........................................................................ 106

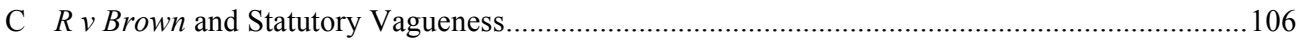

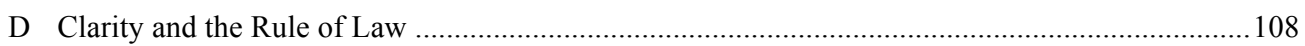

III The Common Law Position in New Zealand .............................................................................................. 109

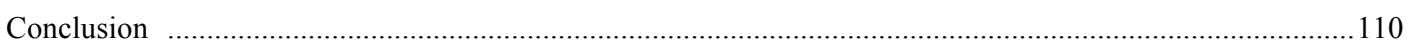

\section{INTRODUCTION}

The case of $R v$ Brown $^{1}$ highlights the tension that exists between the operation of the criminal law, the principle of autonomy, and the scope of the defence of consent. The primary article by Jordan Moulds raises the issue of the influence of statutory alterations to the common law definition of consent through s 22 of the Criminal Law Consolidation Act 1935 (SA). It argues that s 22 leaves the way open for the defence of consent to apply in Division 7A offences arising out of sadomasochistic practices. However, while s 22(3)

LLB (Hons), PhD candidate, School of Law, University of South Australia.

[1994] 1 AC 212 ('Brown'). 
states that ' $[\mathrm{a}]$ person may consent to harm (including serious harm) if the nature of the harm and the purpose for which it is inflicted fall within limits that are generally accepted in the community', the list of examples following s 22(3) does not specifically include sadomasochistic acts.

The problem with s 22 is that the words 'generally accepted' leave open the possibility that the state could still act as an enforcer of 'morals' because an individual judge perceives particular behaviours as 'sexual evils." ${ }^{2}$ This perception of 'sexual evils' is a throwback to Victorian priggishness. ${ }^{3}$ It is an attitude exemplified in Lord Devlin's criticism ${ }^{4}$ of the recommendation in the 1957 Wolfenden Report of the Committee on Homosexual Offences and Prostitution that homosexual acts between consenting adults should be decriminalised. ${ }^{5}$ But, contrary to what Lord Devlin predicted in $1959,{ }^{6}$ society has not disintegrated. ${ }^{7}$ Morality, then, is not a sound basis for determinations of criminality in private sexual matters, particularly when it is difficult to achieve consensus on what is moral. ${ }^{8}$ Those determinations should be made by reference to the common law approach to the issue of consent. $^{9}$

It is arguable that the defence of consent should not be circumscribed to the extent that it was in Brown for three reasons: the first is based on maintaining the coherence of the law; the second arises from the importance of valuing the liberty of individuals in cases where a statute is vague; and the third is found in the value of autonomy. This comment argues in Part I that there should be coherence between tort law and criminal law as to the role of autonomy in setting the threshold at which consent will no longer afford a defence. Part II argues that the liberty of individuals should not be so easily sacrificed where the statute allegedly governing the impugned behaviour is

2 See also Chris Ashford, "Barebacking and the "Cult of Violence": Queering the Criminal Law’ (2010) 74(4) Journal of Criminal Law 339, 340.

3 See Christie Davies, 'Sexual Taboos and Social Boundaries' (1982) 87(5) American Journal of Sociology 1032, 1049.

4 Lord Devlin, 'Law, Democracy and Morality' (1962) 110 University of Pennsylvania Law Review 635.

5 United Kingdom, Report of the Committee on Homosexual Offences and Prostitution, Cmd 247 (1957).

6 Devlin, above n 4, 638.

7 See generally Yves Caron, 'The Legal Enforcement of Morals and the So-called HartDevlin Controversy' (1969) 15(1) McGill Law Journal 9, 35.

8 See also Ronald M Dworkin 'Lord Devlin and the Enforcement of Morals' (1966) 75 Yale Law Journal 986.

9 There must be a line drawn somewhere of course. That line, as will be argued, should be drawn at the infliction of serious harm. 
vague; and Part III concludes that the common law position on consent in New Zealand serves as an example of an acceptable balance between the autonomy of the victim and the role that the criminal law has to play in reducing threats to peace and order.

\section{TORT LAW AND CRIMINAL LAW}

\section{A The Principle of Autonomy}

The common law recognises that the principle of autonomy is one of broad application. As stated by McHugh $\mathrm{J}$ in Perre $v$ Apand:

One of the central tenets of the common law is that a person is legally responsible for his or her choices. It is a corollary of that responsibility that a person is entitled to make those choices for him or her self without unjustifiable interference from others. In other words, the common law regards individuals as autonomous beings entitled to make, but responsible for, their own choices. The legal doctrines of duress, undue influence and criminal liability are premised on that view of the common law. ${ }^{10}$

So, the principle affirms that we have control over access to our bodies. ${ }^{11}$ But, the degree to which we can consent to the infliction of harm upon those bodies varies between tort law and criminal law, as a result of the decision in Brown.

\section{B The Competing Principles of Autonomy and Bodily Integrity}

Perhaps this confusion arises out of the context in which the competing principle of bodily integrity has been discussed by the courts. In Collins $v$ Wilcock, ${ }^{12}$ a criminal case involving an appeal against a conviction for an assault on a police officer, Goff LJ stated that ' $[\mathrm{t}]$ he fundamental principle, plain and incontestable, is that every person's body is inviolate.' ${ }^{13}$ The judgment affirmed that the principle of bodily integrity is a central tenet of the law of battery in both criminal law and tort law. ${ }^{14}$ However, Collins turned on whether Wilcock, the police officer concerned, had acted within

10 (1999) 198 CLR 180, 223 [114] (emphasis added).

1 Ibid; Julia Davis, Connecting With Tort Law (Oxford University Press, 2012) 478.

12 [1984] 1 WLR 1172.

13 Collins $v$ Wilcock [1984] 1 WLR 1172, 1177 (Goff LJ) ('Collins'); see also $R$ v Brown [1994] 1 AC 212, 259-60 (Lord Mustill).

14 See Davis, above n 11, 131-2. 
the powers conferred on her by statute. ${ }^{15}$ The court found she had not. ${ }^{16}$

\section{Bodily Integrity is Not the Only Issue}

Collins was, ironically, a case about the limits of state power. I say ironically because in Brown we have what I consider to be an overreach of state power when taking into account the private nature of the appellants' conduct. Strange, then, that Collins should be invoked by Lord Jauncey to cloak the appellants' behaviour in Brown with a non-existent attitude of hostility and consequently to characterise their actions as unlawful. ${ }^{17}$ Better, as Lord Mustill observed in Brown, to see Collins as an example where the 'perpetrator has acted in a situation where the consent of the recipient forms one, but only one, of the elements which make the act legitimate. ${ }^{18}$ Hostility, then, is one, but not the central, issue to be considered. Lord Mustill's keen observations prompt an inquiry into the symbiotic role of consent and the principle of bodily integrity, and the reasons for their universal application.

\section{What Tort Law Says About Consent}

If a plaintiff in a tort case has consented to a battery, damages will not normally be recoverable unless excessive force or a weapon was used. ${ }^{19}$ This holds true even if the conduct was illegal. ${ }^{20}$ So, in tort law, the defence of consent is no longer available when the harm consented to reaches the threshold of serious harm. ${ }^{21}$ The important point here is that even though there is, initially, a low fault threshold, ${ }^{22}$ the existence of consent by the plaintiff 'raises' the harm threshold to the level of, but not including, serious harm.

\section{E What Brown Said About Consent}

Contrast the situation in tort law with that of the criminal law since the decision in $R v$ Brown. In Brown it was held that the defence of consent is not available where the harm consented to reaches the threshold of actual harm. ${ }^{23}$

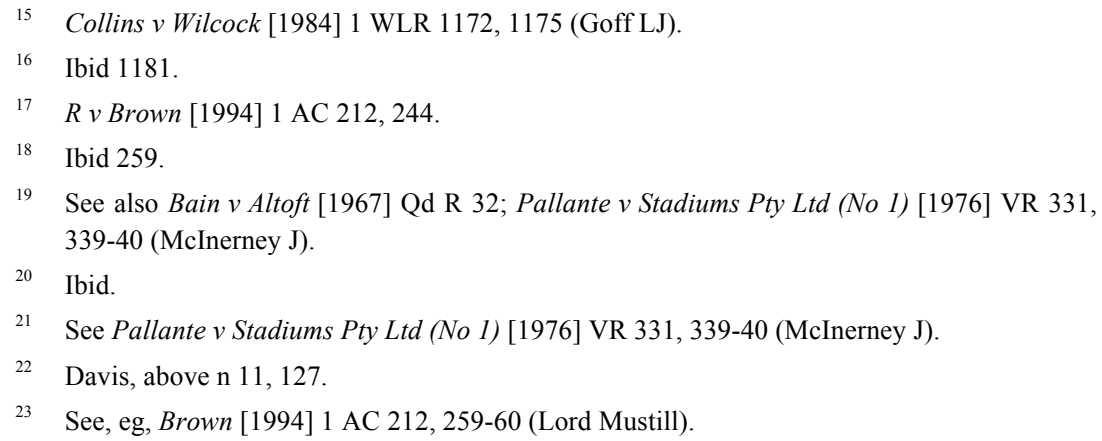


So, in criminal law, the test uses actual harm as a reference point, whereas in tort law it is serious harm. The issue then arises, should there be such a difference between these two bodies of law, both of which aim to protect our bodies and maintain respect for our autonomy?

\section{F The Coherence Factor}

The principle of coherence would suggest that both tests should be the same; as Sir Owen Dixon explained in 'Concerning Judicial Method', the courts should develop the law, maintain its continuity and preserve its coherence. ${ }^{24}$ Of course, the criminal law can limit autonomy in the case of threats to peace and order, ${ }^{25}$ but should the practice of sadomasochism between consenting adults in private homes be considered a threat to peace and order? If it does not result in serious harm, I think not. Why? Because the liberty of the accused is at stake. And when an individual's liberty is on the line, principles, in this case, the principles of coherence and autonomy, must be trumps. $^{26}$

\section{VAgueness, The Rule of Law And Limits on State Power}

\section{A Vagueness of the Statute in Brown}

The appellants in Brown were charged under the Offences Against the Person Act 1861, 24 \& 25 Vict, c 100. This Act has been criticised by the Law Commission for England and Wales for making "use of vague and general terms which have needed a considerable amount of judicial interpretation. ${ }^{27}$ In particular:

Section 18 speaks of "causing" grievous bodily harm to any person, while section 20 speaks of "inflicting" grievous bodily harm on another person. Some other sections, such as section 29 , speak of "doing" grievous bodily harm, while section 47 speaks of assault "occasioning" actual bodily harm. Each of these terms is defensible, if taken on its own, though perhaps "inflict" is not now a word in very common use. It is the use of all four in

24 Sir Owen Dixon, 'Concerning Judicial Method', (1956) 29 Australian Law Journal 468, 475; See also Sullivan v Moody (2001) 207 CLR 562, 581 [55]; Heydon J in Momcilovic v The Queen (2011) 245 CLR 1, 156 [392].

25 Mark Findlay, Stephen Odgers and Stanley Yeo, Australian Criminal Justice (Oxford University Press, $5^{\text {th }}$ ed, 2014) 16.

26 Ronald Dworkin, Taking Rights Seriously (Duckworth, 1994) 22.

27 Law Commission for England and Wales, Reform of Offences Against the Person: $A$ Scoping Paper, Consultation Paper No 217 (2014) 79 [3.79(1)]. 
the same statute that is confusing. ${ }^{28}$

The use of s 20 and s 47 of the Act was challenged in Brown. ${ }^{29}$ Should a statute that is 'confusing' be so readily applied in the case of harm arising out of consensual sexual encounters? Not if the concept of the rule of law is brought to bear on the argument.

\section{B The Rule of Law and Restrictions on State Power}

The law functions as a social instrument that serves to guide human behaviour. ${ }^{30}$ This is an idea that is found in the concept of the rule of law. ${ }^{31}$ On the other hand, the rule of law demands that there should be limits to that guidance, particularly when it allows state power to impinge on personal freedom. ${ }^{32}$ Raz postulates that those limits on personal freedom are governed by two major constraints:

(1) the prohibition of certain forms of behaviour which interfere with personal freedom and (2) the limits imposed on the powers of public authorities in order to minimize interference with personal freedom. The criminal offences against the person are an example of the first mode of protecting personal freedom, the disability of the government to restrict freedom of movement - an example of the second. ${ }^{33}$

The principle of autonomy, as outlined in Perre $v$ Apand and Collins $v$ Wilcock, provides strong grounds for 'disabling' government restrictions on freedom. The defence of consent bolsters the operation of the principle. But, Brown increased the state's ability to limit freedom at the expense of the principle of autonomy ${ }^{34}$ because of the 'considerable amount of judicial interpretation ${ }^{35}$ allowed by the vagueness of the Act.

\section{R v Brown and Statutory Vagueness}

When Lord Templeman characterised the behaviour of the appellants in Brown as violent, he agreed that it was properly brought within the scope of the Offences Against the Person Act:

28 Ibid 81 [3.86].

$29 \quad R$ v Brown [1994] 1 AC 212, 212-13.

30 Andrei Marmor, 'The Rule of Law and its Limits' (2004) 23 Law and Philosophy 1, 5.

31 Ibid.

32 See also Joseph Raz, The Authority of Law: Essays on Law and Morality (Clarendon Press, 1979) 220

33 Ibid (emphasis added).

34 Julia Tolmie, 'Consent to Harmful Assaults: The Case for Moving Away from Category Based Decision Making' (2012) 9 Criminal Law Review 656, 657.

35 The Law Commission for England and Wales, above n 27, 79 [3.79(1)]. 
The violence of sadomasochistic encounters involves the indulgence of cruelty by sadists and the degradation of victims. Such violence is injurious to the participants and unpredictably dangerous. I am not prepared to invent a defence of consent for sadomasochistic encounters which breed and glorify cruelty and result in offences under sections 47 and 20 of the Act of $1861 .^{36}$

Some may argue that the appellants' behaviour was, indeed, violent. But, as noted by Lord Mustill, this 'classification' had the detrimental effect of bringing private, consensual conduct within the scope of the Act:

Conduct infringing sections 18, 20 and 47 of the Act of 1861 comes before the Crown Courts every day. Typically it involves brutality, aggression and violence, of a kind far removed from the appellants' behaviour which, however worthy of censure, involved no animosity, no aggression, no personal rancour on the part of the person inflicting the hurt towards the recipient and no protest by the recipient. In fact, quite the reverse. ${ }^{37}$

The vagueness of the Offences Against the Person Act allowed for the prosecution of the appellants for conduct more properly dealt with by another Act. The appellants in Brown could have been charged under the Sexual Offences Act 1967 (UK) c 60, but for the fact that the statutory 12 month time limit for bringing a prosecution had passed. ${ }^{38}$ It is disturbing that the appellants were charged under a statute that did not have sexual offences as its focal point. Lord Mustill expressed that concern, and called on $R v$ Clarence to make his point:

For present purposes, however, I need only quote from the report at $\mathrm{p} 30$ : "such considerations lead one to pause on the threshold, and inquire whether the enactment under consideration could really have been intended to apply to circumstances so completely removed from those which are usually understood when an assault is spoken of, or to deal with matters of any kind involving the sexual relation or act." I too am led to pause on the threshold. ${ }^{39}$

Why the appellants should have been pursued under the Offences Against the Person Act 1861 is hard to fathom. Lord Mustill certainly thought so:

[i]f the prosecution can show that a sexual harming constitutes some other offence, however trifling and however different in character, the prosecution will be able to establish an offence of common assault or an

36 Brown [1994] 1 AC 212, 236.

37 Ibid 257-8

38 Ibid 270-1 (Lord Mustill). See the Sexual Offences Act 1967 (UK) c 60 s 7.

39 Brown [1994] 1 AC 212, 258 Lord Mustill quoting $R v$ Clarence [1888] QBD 23, 30 (Wills J). 
offence under the Act of 1861, even if in its absence the defendant would not be guilty of any offence at all. Surely this cannot be right. ${ }^{40}$

This observation supports the proposition that the use of state power through vague criminal statutes is an abuse of power that should be curtailed, so that the liberty of the individual is treated as paramount. ${ }^{41}$ That is certainly what the rule of law demands.

\section{Clarity and the Rule of Law}

Lack of clarity in law is what Fuller referred to as 'a failure to make rules understandable', ${ }^{42}$ a tenet also known as the 'canon of clarity'. ${ }^{43}$ Luban stresses the importance of the canon where 'broad, vague criminal statutes give the authorities enormous discretionary power to repress activities they dislike. ${ }^{44}$ In the case of vague criminal statutes, "the canon of clarity imposes a strong, not weak, constraint on the content of criminal laws'. ${ }^{45}$ It is arguable, therefore, that this canon permits strong, not weak, defences in the face of prosecutions under vague criminal statutes. ${ }^{46}$

Some may argue, as Marmor does, that vagueness in statutes is to be expected because the nature of language itself will lead to different interpretations of words. ${ }^{47}$ But a lack of clarity can exist only if we believe decent arguments exist for competing interpretations. ${ }^{48}$ The preceding analysis supports the conclusion that the interpretation of the Offences Against the Person Act favoured by the majority in Brown is not founded upon a decent argument. The New Zealand Court of Appeal is, for its own reasons, of the same opinion.

40 Ibid 271 (emphasis added).

41 See also ibid 258 (Lord Mustill).

42 Lon Fuller, The Morality of Law (Yale University Press, 1964) 39.

43 David Luban, 'The Rule of Law and Human Dignity' (2010) 2 Hague Journal on the Rule of Law 29, 31.

$44 \quad$ Ibid 38.

45 Ibid.

46 The canon of clarity has a counterpart in tort law known as the 'certainty principle'. The principle requires that laws affecting individual liberty must be clear and precise. See Davis, above n 11, 481 .

47 See Andrei Marmor, 'Varieties of Vagueness in the Law' (Working Paper No 89, University of Southern California Law School, April 2012).

48 Ronald Dworkin, Law's Empire (Fontana Press, 1991) 352. 


\section{The COMmon Law Position In New ZEALAND}

The case of $R v$ Lee $^{49}$ concerned an appeal from a conviction of manslaughter. ${ }^{50}$ The victim had died as a result of strangulation during an exorcism. ${ }^{51}$ At trial the jury was instructed that the defence of consent did not cover the 'harm' caused. ${ }^{52}$ The trial judge cited Brown in support of that ruling. ${ }^{53}$ On appeal, the conviction was quashed and a retrial ordered on the point of law that the question of consent should have been 'considered in accordance with the common law rules'. ${ }^{54}$ In New Zealand those common law rules provide that the scope of the defence of consent is not contingent solely upon the degree of harm inflicted; the test is not purely result-based. ${ }^{55}$

In deciding what the scope of the defence of consent should be, the New Zealand Court of Appeal, in a unanimous decision, ${ }^{56}$ drew on the speech of Lord Mustill in Brown. ${ }^{57}$ That speech highlighted the difficulty of formulating a 'general theory of consent and violence' that is based on a level of actual harm and is then subject to a number of exceptions. ${ }^{58}$ His Lordship expressed concern at adopting a particular level of harm as a benchmark for the scope of consent, saying:

it is too simple to speak only of consent, for it comes in various sorts. Of these, four spring immediately to mind. First, there is an express agreement to the infliction of the injury which was in the event inflicted. Next, there is express agreement to the infliction of some harm, but not to that harm which in the event was actually caused. These two categories are matched by two more, in which the recipient expressly consents not to the infliction of harm, but to engagement in an activity which creates a risk of harm; again, either the harm which actually results, or to something less. These examples do not exhaust the categories, for corresponding with each are situations of frequent occurrence in practice where the consent is not express but implied. These numerous categories are not the fruit of academic over-elaboration, but are a reflection of real life. Yet they are

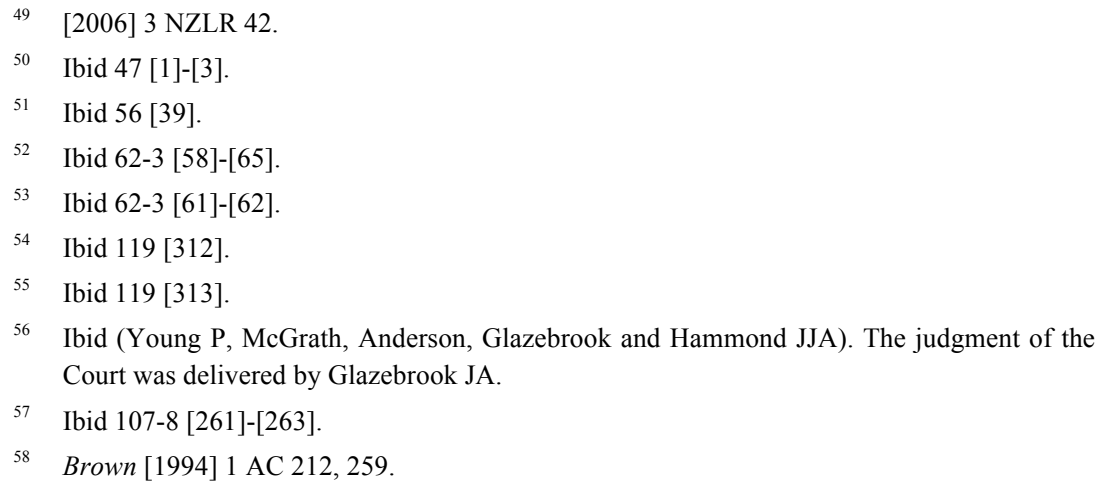


scarcely touched on in the cases, which just do not bear the weight of any general theory of violence and consent. ${ }^{59}$

Relying on this analysis, ${ }^{60}$ the Court of Appeal rejected the pure results-based test from Brown on the grounds that it failed to take into consideration other factors that bear on criminal responsibility. ${ }^{61}$ In particular, the Court determined that a results-based test did not 'give adequate recognition to the personal autonomy of the "victim". ${ }^{62}$ It decided that:

In our view, the rule (for all levels of intentional infliction of harm) is rather that there is an ability to consent to the intentional infliction of harm short of death unless there are good public policy reasons to forbid it and those policy reasons outweigh the social utility of the activity and the value placed by our legal system on personal autonomy. A high value should be placed on personal autonomy. ${ }^{63}$

As always, there are exceptions to any proposition in law. The Court was also of the view that

where grievous bodily harm is intended, public policy factors may require the Judge to withdraw the defence of consent from the jury ... When deciding whether consent should be withdrawn as a defence on public policy grounds in such situations the Judge should take into account the right to personal autonomy, the social utility (or otherwise) of the activity, the level of seriousness of the injury intended or risked, the level of risk of such injury, the rationality of any consent or belief in consent, and any other relevant factors in the particular case. ${ }^{64}$

So, the common law in New Zealand circumscribes the scope of the defence of consent in the criminal law in the same manner as it does in tort law. The bar is sensibly set at the level of serious harm unless there are public policy grounds that, after careful consideration, might dictate otherwise.

\section{CONCLUSION}

If the scope of the defence of consent were to be the same in Australia as it is in New Zealand there would be no need for Parliaments to insert modifications to the common law defence of consent like s 22 of the

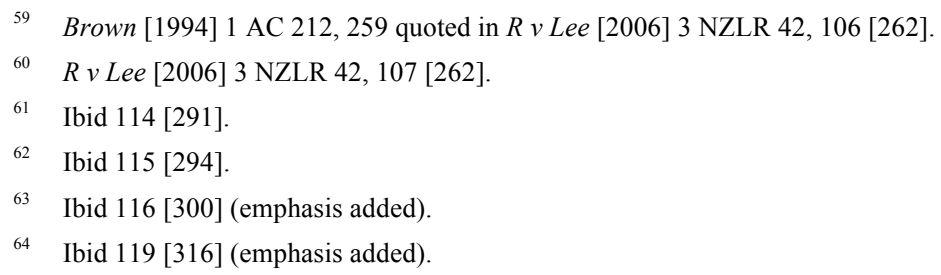


Criminal Law Consolidation Act 1935 (SA). In addition, harm occurring as the result of sadomasochistic activities between consenting adults in private would not likely lead to a conviction in cases where the level of harm is not serious harm or greater. The courts in Australia would do well to extend the same respect for the principle of autonomy that is evident in New Zealand. It is time that the application of that principle ceased to be restricted by outdated morality. 